\title{
From (New)Media to (Hyper)Mediations. Recovering Jesús Martín- Barbero's Mediation Theory in the Age of Digital Communication and Cultural Convergence
}

\author{
Carlos A. Scolari \\ Department of Communication, Universitat Pompeu Fabra - Barcelona
}

carlosalberto.scolari@upf.edu

Roc Boronat, 138 - 08018 Barcelona - Spain

Tel. +34935422000

Carlos A. Scolari has a Ph.D. in Applied Linguistics and Communication Languages (Catholic University of Milan, Italy). He is Associate Professor at the Department of Communication of the University Pompeu Fabra (Barcelona, Spain). He's lectured about digital interfaces, media ecology and interactive communication in more than 20 European and Latin American countries. Most important publications: Hipermediaciones (2008), El fin de los medios masivos (with M. Carlón, 2009, 2012), Crossmedia Innovations (with I. Ibrus, 2012), Narrativas Transmedia (2013) and Transmedia Archaeoloy (with P. Bertetti and M. Freeman).

(a) cscolari - www.hipermediaciones.com

\section{Citation}

Scolari, Carlos A. (2015). From (New)Media to (Hyper)Mediations. Recovering Jesús MartínBarbero's Mediation Theory in the Age of Digital Communication and Cultural Convergence, Information, Communication \& Society 18(9): 1092-1107.

DOI: 10.1080/1369118X.2015.1018299 


\section{Introduction}

Latin America has a long tradition in media research and theoretical production. The development of mass press in the $19^{\text {th }}$ century and the successive emergence of broadcasting encouraged the appearance of the first reflections on the media, the new professional roles and the often-traumatic relationships established between them. The professionalization of the writer in a context of industrialization of literature was one of the most debated issues in the late 19th century (Rivera, 1980). Media studies was formalized very early on: the first School of Journalism was created in Argentina as early as 1934, and was later integrated into the Universidad Nacional de La Plata. However, the great explosion of Faculties of Communication in Latin America occurred in the 1960s under the auspices of the development policies. According to recent research, in Latin America there are 1,742 higher education institutions specialized in journalism, media and communications (FELAFACS/UNESCO, 2009).

The relationships between the Latin American research, the European tradition and the scientific production coming from the United States have never been easy. As we will see in the next section, the Latin American scholars moved from the uncritical acceptation of the Mass Communication Research theories in the 1950s and 1960s to anti-imperialist criticisms of these theories in the 1970s. The relationships with the European tradition, even if complex, have been constant: in the last 200 years Latin American intellectuals, from Argentina to Mexico, have been educated looking towards Europe. In this context the Latin American media scholars, working from different disciplines (anthropology, semiotics, cultural studies, sociology, aesthetics, etc.), made important contributions to the field. As it is almost impossible to summarize this complex network of theoretical exchanges, negations, translations and adaptations in a few pages, this article will focus on a single theoretician: the Spanish-Colombian researcher Jesús Martín-Barbero (JMB). 
Reference figure in Latin American communication studies since the 1980s, JMB is considered the key researcher of this scientific production: his transdisciplinar vision, his constant interpretation of the key European reflections from a Latin American point of view, and his epistemic location beyond the traditional paradigms place him at the center of a new generation of researchers who refounded the communication and cultural studies in Latin America.

The objectives of the article are:

- To introduce JMB's main conceptions and categories to non-Latin American scholars.

- To recover JMB's innovative contributions almost three decades after their original enunciation now within the context of a new media and cultural environment.

- To identify some appropriations and possible connections between JMB's theories and contemporary approaches to new digital media and cultural convergence.

The first section of the article briefly describes the origin and development of communication studies in Latin America since the 1950s. This description is essential for understanding the scientific and discursive context in which JMB's theories emerged in the early 1980s. The second section is focused on JMB's most important book $-D e$ los Medios a las Mediaciones. Comunicación, cultura y hegemonía (1987) (English edition: Communication, Culture and Hegemony. From the Media to Mediations, 1993) - and outlines his main contributions and the interpretations they have generated over the past 25 years. In the third and fourth sections the article explores JMB's production from the perspective of the contemporary media and culture environment, a brand new 
territory characterized by digital social networks, collaborative practices, and transmedia narratives, placing particular emphasis on the possible connections between JMB's mediations and Henry Jenkins' convergence culture (Jenkins, 2004, 2006a, 2006b; Jenkins, Ford \& Green, 2013).

Why this long-distance dialogue between JMB and Henry Jenkins in section four? Firstly because both scholars, even though they worked in different academic environments, followed similar research paths. Both of them started their academic careers analyzing narratives, genres and discourses (Martín-Barbero, 1978; Jenkins, 1992) and then migrated to cultural issues. In both cases they moved from the content of media (telenovelas, vaudeville) to what the marginal groups (popular classes and fans) were doing with that contents. In their particular academic contexts (Latin America in the late 1970s for JMB, the United States in the early 1990s for Jenkins) both scholars embodied a particular 'cultural turn' that renewed the research agendas of many other scholars and redirected the academic gaze towards marginal practices (active-viewing of the telenovela in the 1980s and the productions of fan communities in the 1990s). How can this comparison help us to understand contemporary cultural convergence? We will try to answer this question in section four.

In other words, the main objective of the article is to recover JMB's contributions from a contemporary perspective, identifying possible dialogues and appropriations. Although JMB's categories were developed for popular communication practices based on broadcasting media, they can be re-interpreted to enrich the theorizations on interactive media, digital communication and cultural convergence.

\section{Media Studies in Latin America}

Theories can be understood as a network of scientific conversations that emerges from an organizational environment made up of universities, research centers, journals, 
conferences and congresses (Scolari, 2009). To comprehend the dynamics of a scientific domain - in this specific case JMB's theoretical discourse - it is necessary to map the discursive territory, identify the interlocutors that participate in the conversations and reconstruct their exchanges.

Describing the evolution of Latin American media conversations implies analyzing the scientific production and, at the same time, reading a volume of contemporary history. In other words: the scientific conversations - not only in the media field - are strongly connected to the political and social processes that affect the different societies. As already indicated, the first local reflections on media started with the diffusion of the mass press in the $19^{\text {th }}$ century, when issues like the author's role in the new media environment and the relationships between the professional writer and the cultural industry were part of the intellectual agenda (Rivera, 1980). After the consolidation of electronic media (radio in the 1920s and television in the 1950s) Latin American communication studies could be roughly divided into two distinct time periods: 1) a first stage, which extended from the 1950 s to the late 1970 s, characterized by a more or less uncritical acquisition of the hegemonic theories coming from the United States and Europe; and 2) a second period, from the early 1980s to the present, characterized by a theoretical production of its own that looked for a dialogue with the European tradition but, at the same time, never excluded a critical interpretation of the production coming from Europe and the United States.

\subsection{The arrival of Mass Communication Research (and its detractors)}

Mass Communication Research arrived in Latin America in the same suitcase as development policies. It should be noted that John F. Kennedy's Alliance for Progress also included a chapter about communication development. The Centro Internacional de Estudios Superiores de Comunicación para América Latina (CIESPAL), an 
institution created in 1959 in Quito (Ecuador), was one of the key clusters of this theoretical migration: in CIESPAL the works of major communication for development theorists - from Everett Rogers (1962) to Wilbur Schramm (1964) - were translated and distributed across the continent. In the mid-1960s the recently created communication faculties taught the two-step flow of communication, the information theory model and the best techniques for accelerating the diffusion of technology in rural areas.

But this optimistic and instrumental vision of communication - which considered the media as a tool for economic and social development - would soon be supplanted by a critical and no less instrumental approach. In the late 1960s the political situation of the subcontinent radically changed: the promises of development were part of the past and the new reality was made of liberation movements, urban guerrillas and anti-imperialist discourses. In this new context the crossover between dependency theories (Cardoso \& Faletto, 1969), the French semiology interested in discovering the ideology hidden in mass culture (Barthes, 1957), and the structural marxism (Althusser, 1971) generated the breeding ground for a paradigmatic shift. In Latin America the media ceased to be considered an instrument of development and became suspected of being an instrument of domination.

At the end of the 1970s most Latin American revolutionary movements, especially in the southern countries, had been aborted by bloody dictatorships. As human rights violations were part of everyday life, many communications researchers were forced to go into exile. In many countries the scientific production, not only in the field of media studies, entered into a cone of shadow that would last almost a decade. This is the context in which JMB's theoretical discourse emerged in the late 1970s-early 1980s. 


\subsection{A brand new approach: Communication and popular cultures}

In a seminal text published in 1980 (Retos a la Investigación de Comunicación en América Latina - Challenges to Communication Research in Latin America), JMB described the new coordinates of communication research in Latin America. The dictatorships were in decline and the new 'under-controlled democracies' as JMB defined them (1980, p. 2) were the context for the emergence of a new theoretical paradigm. The cultural situation was also different: the fragmentation and complexity of the societies ran parallel to the introduction of 'new technologies' (satellite, cable television, VHS players, etc.) and the consolidation of the mass media at the center of the political-economic system. In this context JMB developed a harsh critique of the previous communication research in Latin America:

Critical research in the social sciences, and particularly in mass communication, has mainly been defined in Latin America by its rupture with functionalism. But maybe this rupture was more affective than effective; functionalism has been disqualified "in theory" but in practice it is still being applied (by scholars) ... The instrumentalism of functionalism, even if covered with a veil of Marxist theory, cannot break the verticality and the unidirectionality of the communication process because it feeds on them' (1980, p. 5-6).

JMB was one of the first scholars to identify the epistemological continuity between the instrumentalism of the development theories and the instrumentalism of the Marxist-structural approaches. It is a remarkable fact that two scientifically and ideologically irreconcilable approaches ended up sharing the same instrumental view of communication. Oversimplifying, it could be said that in the 1950s to the 1970s Latin American media studies were a great sounding board for the communication theories and conceptions born in the United States and Europe. JMB also criticized the universities for teaching a mix of 'functionalism-structuralism-Marxism', a combination 
totally divorced from the history, the problems and the disciplines of where these theories came from. At the same time, JMB pointed out the limits of the methods, both quantitative - employed to measure the effects of media - and qualitative - interviews and questionnaires employed to address the interpretation processes of social groups (p. 9-10). Finally, JMB was also one of the pioneers in the reconfiguration of media reception studies. Many Latin American scholars, in line with the critical tradition, had often considered subjects as accomplices of domination, but according to JMB they should also be considered as decoders and replicators of the domination discourses (1980, p. 11). In other words: in the reception space there is room for domination and, at the same time, for resistance and re-signification.

But probably JMB's most important contribution came from a new mapping of the relationships between popular and mass culture. One note before continuing: the conception of 'popular' culture in Latin America is completely different from the Anglo-American one. If traditional media studies in the United States homologated 'popular' and 'mass' culture (usually they're considered as synonyms), in Latin America 'mass culture' refers to the homogenized cultural industry - in the sense of Adorno \& Horkheimer (2002) - while 'popular culture(s)' relates to the folkloric, preindustrial and/or the culture of the subaltern classes from a Gramscian perspective. In the early 1980s JMB and many other Latin American scholars went beyond this opposition to 'highlight how popular culture circumvents the perceived power of international media industries and gives voice to popular demands and interests' (Schlesinger \& Morris, 1997, para. 36). JMB proposed thinking about social identity in relation to popular culture without forgetting that popular culture has deeply modified the forms of expression of mass culture.

From JMB's perspective the relationships between mass and popular cultures 
could be understood and presented under different practices:

- $\quad$ Popular as a memory of a forgotten cultural matrix. It includes resistance and replication discourses (and silences). More than a folkloric recuperation of the past, the popular culture is constructed in opposition to a dominant practice (1980, p. 20).

1. Popular-massive: mass culture denies popular cultures. The former is industrially produced 'for the masses'; it homogenizes the popular culture(s) and dissolves their differences (1980, p. 21). But at the same time JMB considered that there existed a 'historical mediation': mass culture needs and reappropriates popular culture and, at the same time, reconfigures the 'popular taste' (gusto popular). How many times did media researchers condemn the alienation of 'mass culture' when, in practice, they were condemning the popular components inside it? According to JMB a classist conception of the taste of the popular (subaltern) classes is hidden behind many critical theories of mass media.

For JMB the relationships between the popular and the mass cultures should not be reduced to mutual exclusion: rejection and hybridization operate together. The two cultures blend into each other but, at the same time, they also include negation movements (see Figure 1).

\section{Figure 1. Popular cultures / Mass culture}

JMB was not alone in this reconfiguration of communication research in Latin America. Scholars like Néstor García Canclini (1993, 1995), Jorge González (1996), Renato Ortiz (1985), Aníbal Ford, Jorge Romano and Jorge Rivera (Ford, Rivera \& Romano, 1985) or Guillermo Orozco Gómez (1996) - just to mention a few - were also active actors in the same academic movement. 
Without rejecting the confrontation and dialogue with the works of scholars from the United States and especially Europe, this emergent paradigm was characterized by an original conception of media, communication and culture that broke with the instrumentalism present in Latin American research in the 1960s and 1970s. Even though it is not the objective of this text to analyze the causes that modeled Latin America communication research in the 1980s, we can hypothesize two sets of conditions that fostered the 'cultural turn':

- Epistemological conditions: Latin American researchers identified many limitations in former paradigms, from the traditional Mass Communication Research and development theories to the French critical reproductivist theories. The strong opposition to empirical research coming from the United States denounced by Mattelart (1970) in the early 1970s was still alive in the 1980s and 1990s. JMB was one of the most lucid critics of that 'left functionalism according to which the system is reproduced terribly, automatically and through each and every social process' (Martín-Barbero, 1980, p. 10). These epistemological tensions were the melting pot from which the new Latin American cultural paradigm emerged.

- Socio-economic conditions: Most of the media and communication research in Latin America has been financed by public institutions. The connections and complicities between researchers and the media industry have been very limited. In this context the research has mainly focused on social and political issues rather than on market or industrial issues. This disconnection between the scholars and the industry will be basic for understanding the differences between JMB and Jenkins' approaches (see section 4). 


\section{From Media to Mediations}

JMB's most important contribution to cultural studies and media research was published in 1987 under the tittle De los Medios a las Mediaciones. Comunicación, Cultura y Hegemonía. It is not an easy task to summarize this book: in its pages JMB deploys all his erudition to describe how the popular classes have become a historical subject in the Western world. His tour begins with the diffusion of popular literature in the late $18^{\text {th }}$ century in Europe, continues with the establishment of the cultural industry in Latin America (press, radio, television) and finishes by mapping the territory where the cultures of the popular classes dialogue with and confront mass culture. After the crisis of the 'imperialism thesis' - which considered the automatic transmission of ideology from metropolitan centers to peripheral receivers as an accomplished fact - Latin American researchers turned to the study of the real conditions of reception and consumption of cultural products in the context of popular cultures. JMB was at the center of this epistemological turn. His program could be summarized in a set of paradigmatic mutations:

- From the critical analysis of content to the exploration of the media reception conditions in the context of popular cultures: In the telenovelas stories are strongly connected to oral narrative traditions. There is an exchange and at the same time a confusion between the fictional story and real life, between what the actor does on the screen and what happens to the spectator. JMB demonstrated that the real challenge for media studies was not to identify the hidden ideology of telenovelas but to understand what the viewers 'did' with them.

- From cultural domination to considering popular classes as active historical subjects: According to Schlesinger it was important to JMB 'to rescue the category of "the people" from elite theorists (whether conservative or Marxist) who identify the popular with "the masses". Popular culture, under 
contemporary conditions experienced as mass culture is not to be dismissed as an absence of culture' (Schlesinger, 1993, p. xii).

- From cultural homogenization to the national cultures understood as a permanent conflict between ethnic groups, classes, religions, regions and cultures: JMB went beyond the traditional conceptions (either the old imperialism or the new transnationalization thesis) and showed how the construction of a national culture is a never-ending process that involves multifold transactions and is far from being uniform.

- From media to mediations: JMB defined his epistemological turn as a displacement from the object (the media) to the social process (the mediations). In the first pages of De los Medios a las Mediaciones he wrote: Communication began to be seen more as a process of mediations than of media, a question of culture and, therefore, not just a matter of cognitions but of recognition $[\ldots]$ We are also recognizing that in recent years the term 'popular' does not apply just to native American or peasant cultures, but also to the thick layers of mestizajes or mixtures and in that deformed evolution of urban, mass culture, found in the enormous new settlements surrounding Latin American cities (Martín-Barbero, 1993, p. 2).

In this context of theoretical refoundation 'mediation' becomes a central analytical category that goes beyond media research. The concept of 'mediation' - not to be confused with 'mediatization' - entails looking at how culture is negotiated and becomes an object of transactions in a variety of contexts. Mediations could be considered as a social interface, a place from which it is possible to perceive and understand the interactions between the space of production and the space of reception. Media do not only respond to the requirements of the industry and commercial 
strategies but also take into account (and represent) the desires and perspectives of the popular classes: they play a major role in popular culture by offering images and themes that evoke powerful forms of identification. To conclude this brief presentation of JMB's contributions we could say that this eclectic scholar developed a nonmediacentric theory of culture and communication. JMB seems to tell us to forget the cathode tube, forget the gadgets, forget the box, and instead he invites us to analyze communication processes from the standpoint of cultural practices and social movements.

\section{From New Media to Hypermediations}

How useful are JMB's theoretical contributions in a context where social networks are challenging the hegemony of traditional broadcasting media and the spectators, who have now been transformed into prosumers, remix texts and distribute them on the digital platforms? Could a theory inspired by the active reception of telenovelas and the tensions between popular cultures and mass culture survive in a new environment characterized by the convergence of participatory amateur culture and the media industry (Jenkins, 2004, 2006a, 2006b)? In an interview conducted in 1999 by Adelaida Trujillo, almost twenty years after his seminal article of 1980, JMB was asked what he considered was the most immediate challenge for communication studies. Without giving up the omnipresent question of power, his answer was clear about the eruption of technological issues in the media research agenda:

How do we account for the social significance of the new communication technologies, their presence across everyday activities from the workplace to moments of leisure, from science to politics? How do we avoid technological determinism? How do we deal with questions of inequality and power, engaging them as challenges to communication thinking? (Martín-Barbero, 1999, para. 
$31)$.

In this section and the next one the article addresses these and other questions that arise in the borderland between mediations, digital technology and cultural convergence.

\subsection{Towards a Definition of Hypermediations}

Let's begin from JMB's question: How do we account for the social significance of the 'new communication technologies'? To answer this we can start by recuperating his epistemological proposal, that is, the transition from the object to the process. How can this be redefined considering the deep transformation of the media and cultural practices since the arrival of the World Wide Web and the emergence of new mobile media, social networks and transmedia textual formats? If JMB gave up the media (object) in order to gain the mediations (process), now it is possible to reproduce this movement; that is, to give up the 'new media' (object) in order to gain the 'hypermediations' (process) (Scolari, 2008). In this context we can understand the hypermediations from a double perspective:

- Hypermediations as a set of socio-technological processes and experiences: When we talk about hypermediations we are not referring to either a product or a specific media but to the complex network of social production, exchange, and consumption processes that take place in an environment characterized by a large number of social actors, media technologies and technological languages. The Greek prefix hyper means 'excess' or 'exaggeration', but also 'over', so hypermediation is more than a high number of interconnected media and subjects: the concept includes the political and social conflicts already detected by JMB in the 1980s in his analysis of popular and mass cultures. Like Fidler's mediamorphosis (1997), the analysis of hypermediations leads us to investigate 
the emergence of new social, political, and cultural configurations beyond those generated by traditional broadcasting media.

- Hypermediations as a theoretical field and a research program: If we consider that theories are conversations that are expressed in papers, articles, books, classrooms, research labs and conferences, in the last two decades hundreds of Latin American researchers have joined the conversation about the 'new media' from a perspective more or less inspired by JMB's contributions. However, hypermediations reconfigure communication research with respect to the mediations in the 1980s, introducing new objects, methodologies and challenges.

\subsection{Hypermediations as a Set of Socio-Technological Processes and}

\section{Experiences}

What are then the main differences between mediations and hypermediations? The new media ecosystem has re-configured the traditional symbolic exchange processes in many ways, a fact that, obviously, affects the ways they can be tackled from a theoretical point of view. When we go from the object to the process we are constrained to referring to the new cognitive, social and cultural dynamics that digital technologies have instituted. Let's briefly map this new environment.

JMB's theory of mediations was built around the experience of broadcasting and the active popular responses to it. In the 1980s the media ecosystem was founded on analog technologies, the media content was mostly organized in linear textual structures and the audiences were seated in front of the TV set. The introduction of digital technology facilitated the manipulation, reproduction and exchange of information in a global network (from one-to-many to many-to-many). Digital technology also enhanced the creation of more complex textual structures (from text to hypertext) and the confluence / hybridization of different languages (from monomedia to multimedia). In 
the broadcasting era the different actors of the system (professionals, companies, researchers, etc.) thought in a monomedia mode: the audiences were classified and the transmission strategies were organized around single media (radio, television, cinema, etc.). Now 'transmedia' seems to be the magic keyword (Jenkins, 2006b). Nowadays it is almost impossible to develop production or research strategies without taking into account the relationships between media in the context of the media ecology (Scolari, 2012).

If we look at the audiences we see that the critical, rebellious and counterhegemonic subject identified in the 1980s is now a prosumer that actively participates in the creation of texts to feed the social networks. Remixing, postproduction and usergenerated contents are the new coordinates of media consumption practices. The traditional viewing or reading experiences have also been transformed: today users deal with high-interactive interfaces that go beyond the traditional TV channel surfing or browsing the printed page. Finally, if JMB's theory of mediations analyzed the tensions and mutual appropriations of mass culture and popular cultures, the hypermediations should focus on the tensions and mutual appropriations of mass culture and participatory culture, a new experience that Jenkins (2004, 2006b) defined as 'convergence culture'.

JMB's analysis of mediations was also part of a well-defined social and political process: the establishment of a historical subject since the beginning of Modernity - but with deep roots in the medieval popular cultures - in which, according to JMB, the mass media, like the press, the radio and the television, play a key role. This three-century old process has been undergoing a profound mutation since the diffusion of the World Wide Web, the explosive combination of social networks and mobile devices, and the emergence of new cultural production/consumption practices (Scolari, 2009). It is also 
necessary to remember that today the collective identities and the mass media do not have the homogeneity they enjoyed in the golden ages of Modernity. At the beginning of the $21^{\text {st }}$ century the social identities are fluid and media experiences have fragmented into millions of individual consumption situations, in different places, devices and times. In this context we can return to the basic principle that inspired JMB's mediations: to give up the new media (the object) in order to gain the hypermediations (the social process) also means that all of those processes are enacted - in the double sense of 'performed' and 'represented' - by a broad spectrum of social actors, from Hollywood majors to radical movements, each of them implementing their own domination strategy and resistance tactic. As Castells put it:

Not only public space becomes largely defined in the space of communication, but this space is an increasingly contested terrain, as it expresses the new historical stage in which a new form of society is being given birth, as all previous societies, through conflict, struggle, pain, and often violence (Castells, 2007, p. 258).

\subsection{Hypermediations as a Theoretical Field and a Research Program}

What should a researcher working within the hypermediations framework analyze? More than media-objects the researcher should study the media-processes mentioned above, not only from the perspective of the 'new' but also in the context of a dynamic ecology of communication. Traditional mediation studies have mainly focused on certain media (radio, television), languages (written, audio-visual) or genres (telenovelas, graffiti, etc.), but in the field of hypermediations the media languages converge, genres hybridize and new interactive textual networks emerge. Unlike mediation, which focused on the construction process of a national-modern society in a 
delimited geographical space, hypermediations focus on the critical constitution of the global-postmodern society in a virtual/real blended territory.

If the mediation approach proposed analyzing the links between communication practices and social movements, the research agenda of the hypermediations invites us to forget the 'new thing' and to analyze the social transformations that the new forms of communication are generating. The hypermediation approach also vindicates the active role of the receiver (that is, the active role of the user), introducing another level of continuity with one of the fundamental assumptions of JMB's theory of mediations. To remove the simple visions that only see either manipulations or ideological conspiracies in telenovelas or videogames, and to show the complexity of the interpretation and interaction processes, are two theoretical tasks that the analysis of hypermediation processes brings back to the foreground. Finally, the theoretical perspective of the hypermediations should contribute to eradicating the linearities of Shannon's model that still survive in certain areas of media research.

With appropriate adaptations the analytical program outlined by JMB in the 1980s for analyzing media contents ad popular cultures, which was never completely deployed, remains useful:

'What is important is that which structures the specific conditions of production and the ways the productive system leaves marks on the formats. Thus, the focus is on the ways in which the television industry, as a productive structure, semanticizes and recycles the demands coming from the various ""publics" and the uses of television by these publics' (Martín-Barbero, 1993, p. 221).

JMB proposed to "take the study of reception out of communication defined as circulation of messages, effects and reactions' (p. 221-222). The study of media reception should be placed 'into the field of culture: the conflicts which articulate 
culture, the mestizajes which weave it together with the anachronisms which sustain it' (p. 222). Last but not least, the analysis of reception should pay attention to the 'persistent functions of appropriation and repetition by the subaltern classes' (p. 222). This program, adapted to the new socio-technological conditions, retains all its validity. The following table summarizes the transition from mediations to hypermediations:

\section{Table 1. Mediations and hypermediations}

These differences between mediation and hypermediations should not generate the idea of two separate theoretical universes. There are more continuities than breaks in the path from mediations to hypermediations. The new (hyper)media practices and processes do not cancel out mass media's past, but rather emerge from that environment and transform it. If JMB's mediations implied the loss of the fascination with the object (the media) and the retrieval of the social process (the mediations), hypermediations imply the loss of the fascination with the object (the new media) and the retrieval of the new social processes. In other words: hypermediations do not contradict mediations, they just look at the communication processes from a slightly different perspective that integrates the new experiences and introduces new analytical categories.

\section{Between Mediations and Cultural Convergence}

This section focuses on just one of the oppositions identified in Table 1: if in the 1980s JMB developed a theory of mediations around the opposition between mass culture and popular cultures, today many theoretical conversations on media and culture tend to be organized around the opposition between the media industry and participatory culture. Topics like the participation of fans, their textual productions (fanfiction, user-generated contents, etc.) and new roles (prosumers, produsers, etc.) have become increasingly more present in the latest communication research. Although scholars like Jenkins 
(2006a, 2006b) have focused primarily on the participatory creative cultures, this phenomenon occurs within a much larger cultural and social movement (Busse \& Hellekson, 2006; Cova, Kozinets, \& Shankar, 2007; Deuze, 2007; Gray, Sandvoss, \& Harrington, 2007; Delwiche \& Henderson, 2013).

Jenkins - one of the most relevant cartographers of this 'collision' between old and new media - defines 'convergence culture' as the place where 'grassroots and corporate media intersect' (Jenkins, 2006b, p. 2). From the first pages of Convergence Culture (2006b) Jenkins stands back from technological determinism. He states that convergence should not be understood primarily as a technological process that merges multiple media functions within the same devices, but rather convergence 'represents a cultural shift as consumers are encouraged to seek out new information and make connections among dispersed media content' (p. 3). Media convergence is more than a technological shift:

Convergence alters the relationship between existing technologies, industries, markets, genres, and audiences. Convergence alters the logic by which media industries operate and by which media consumers process news and entertainment $[\ldots]$ Keep this in mind: convergence refers to a process, not an endpoint (p. 15-16).

In this framework Jenkins indicates a series of traits of the contemporary media industry: reduction of production and distribution costs, increased number of delivery platforms and channels, and a high concentration of ownership. Moreover, audiences have generated new forms of participatory culture and media consumption has become a 'collective process' that is changing 'the ways religion, education, law, politics, advertising, and even the military operate' (p. 4). It is almost impossible to reduce the convergence process to a single dimension: 'convergence, as we can see, is both a top- 
down corporate-driven process and a bottom-up consumer-driven process' (p. 18).

This brief description of Jenkins' cultural convergence paradigm should be enough to identify some 'convergences' - and also divergences - between his reflections and JMB's contributions on mediation. Although JMB's theories were developed in a very different media and cultural environment from Jenkins's world of transmedia storytelling and networked fans, it is still possible to identify a series of theoretical connections:

- JMB's and Jenkins' approaches are based on an opposition (mass culture and popular cultures in JMB, media industry and participatory culture in Jenkins) but both of them just use this antagonism as a basic frame for analyzing the relationships between the two opposing elements.

- JMB and Jenkins reject technological determinism. In JMB's terms it could be said that Jenkins also moved away from the media (the technological object) to analyze the mediations (the cultural processes: 'convergence refers to a process').

- JMB and Jenkins started their reflection on media from the people, not from the technological device. If Jenkins got into the culture of convergence hand in hand with the fans and the user-generated contents, JMB started with the telenovela viewers. As he explained in an interview: 'I started with the people's everyday communication. I created the concept of "mediation" to think about that: the actors, subjects, the movements. Because communication is a matter of actors' (Martín-Barbero, 2012, p. 23).

- JMB and Jenkins do not focus exclusively on the texts (telenovelas, videogames, television series, etc.) but rather they are interested in what people do with them. In the specific case of JMB, like many other researchers of his generation, he 
was interested "in what people do with what they see and enjoy, the logic of production, and the composition of the narrative text. We were interested in being in the three moments: the uses of the people, the text and the way of giving them a sense" (2012, p. 29). Jenkins, for his part, is interested in the collaborative production processes and the collective intelligence that is expressed via the prosumers' activity.

Although there are many similarities between the two approaches, it is almost imperative to mention the differences between them:

- It could be said that Jenkins' approach is much more 'industrial' and marketcentered than JMB's, who developed a theory centered on the interests of Latin American subaltern classes. The mediation approach did not include in its agenda economic aspects like the commercial strategies of the media industry, an issue central in Jenkins' convergence approach.

- Analyzing media practices in the 2010 s is completely different from analyzing them in the 1980s. Even if some textual or ethnographic methodologies - like the narrative analysis of texts or the interview, respectively - are still important, the analysis of the consumers' activity is now supported by a new set of qualitative (i.e. virtual ethnography) and quantitative (i.e. web analytics) techniques.

- Some critics of Jenkins' proposal, like Couldry (2011), pointed out the difficulty of generalizing fans and prosumers' activities to the rest of the audiences. Not all of the users are fans that share videos on YouTube or skilled computer geeks that create machinima. To imagine an army of hundreds of millions of fans producing user-generated contents is an optical illusion that researchers of convergence processes should avoid. JMB's theoretical reflection, however, 
embraced a broader social subject: the Latin American popular classes.

- The most relevant distinction between the two approaches is social. And political. The mediation approach is rooted in the history of popular classes and the political struggles of Latin American people. This political dimension of the mediation processes is reduced to a minimal expression in the convergence approach. The references to 'civic media' - that is, the content 'intended to increase civic engagement or to motivate participation in the political process' (Jenkins, Ford, \& Green, 2013: 219) - or to the 'collective intelligence' (Jenkins, 2006b) are moving in the right direction but they are far away from the social and political interpretation of JMB`s mediation theory.

Let's expand this critical vision of Jenkins' convergence culture. According to Couldry when Jenkins discusses the protopolitics of convergence culture He provides little evidence that the acts he identifies are likely to be associated with progressive rather than with other sorts of politics; and, second, he ignores some obvious contextual factors which might lead to the appropriation of convergence culture for non-progressive politics, above all neoliberal discourse's closing down of the parameters of acceptable political action (Couldry, 2011, p. 497).

For Couldry the only plausible way to understand the politics of convergence is 'to develop a better sociological and cultural analysis of what people are doing with and around media' (p. 497). In this context the contributions of JMB could be really helpful for understanding 'what people are doing with and around media'. To conclude this section, the following table summarizes the similarities and differences between JMB's mediations and Jenkins' convergence culture:

Table 2. Mediations and cultural convergence 
How can JMB's mediations enrich Jenkins' convergence? This comparative analysis of the two theoretical models has profound implications for scholars interested in contemporary cultural processes: while Jenkins seems to be more interested in the 'convergence' - intended as a 'series of intersections between different media systems' (2006: 282) [italics added] - JMB's model proposes a more complex set of relationships between the media industry and popular cultures. As already indicated in section 1.2, for JMB rejection (mass culture and popular cultures negate each other) and hybridization (mass culture needs and reappropriates popular cultures, and vice versa) operate together. In this theoretical context the convergence culture model should integrate rejection (the media industry and participatory culture negate each other) and hybridization (the media industry needs and reappropriates participatory culture, and vice versa).

This double and contradictory movement represents the complex set of relationships between the media industry and participatory culture better. Research on convergence culture has focused mainly on just one-side appropriations: the usergenerated contents produced by fans. However, not only fans take possession and manipulate Hollywood narrative universes: the industry also appropriates fan production - for example, Kindle Worlds, 'a place for you to publish fan fiction inspired by popular books, shows, movies, comics, music, and games' (Kindle, s/d), or the comic Pardillos, a parody of Lost published by a Spanish fan (Scolari, 2013) - and inserts it into the commercial circuit. On the other side, the territory of textual hybridizations is almost infinite and invites an exploration of the 'grey zone' in between the media industry and the collaborative culture that combines the practices of both worlds - see for example the commercial production of auques inspired by Don Quixote at the end of the 19th century in Spain (Scolari, 2014). 
From JMB's perspective Jenkins' participatory culture is just an area - maybe the most active and productive - of a broader social space occupied by many other cultural groups and experiences. In this sense we need a more complete map of popular / subaltern cultures in the new media ecology: if the users that share videos on YouTube are not all fans, then we need to know something else about those who are not fans. What is their position in front of media industry contents? We can imagine a continuum of media culture practices, from the passive TV 'couch potato' to the most (inter)active prosumer who creates user-generated contents and shares them in Fanficion.net or YouTube.

The theoretical dialogue between JMB and Jenkins expands the market-centered vision of convergence studies by analyzing more resistance and replication practices coming from marginal political and social actors. This dialogue indicates a possible path for future studies on convergence culture. And I am not just thinking about 'more sociology, more culture, more politics' as Couldry suggests: convergence studies and their cousin, the research on transmedia storytelling, should go beyond the classic objects and extend to new spaces (i.e. convergence in Latin American countries like in Arcila Calderón, Calderin \& Castro, 2014) and new times (i.e. transmedia practices in the past, like in Scolari, Bertetti \& Freeman, 2014). The following figure summarizes these possible expansions of the convergence culture model:

\section{Figure 2. Expanded convergence culture model}

\section{Conclusions}

In this article I have briefly described the contributions of Jesús Martín-Barbero, the main reference of the 'cultural turn' of Latin American media research in the 1980s; the transition from media to mediations has been the most important epistemological 
revolution - in the sense of Kuhn's 'paradigm shift' (1962) - in the history of Latin American communication studies. In the third section I have reinterpreted JMB's categories from the perspective of contemporary media practices; in this case, the transition from new media to hypermediations proposes a non-mediacentric vision of the contemporary media ecology based on the new processes that characterize this socio-technical environment. As indicated in the third section, JMB's program, adapted to the conditions of the new media ecosystem, retains all its validity. In the fourth section I proposed a dialogue between JMB's mediations and Jenkins' convergence culture, identifying similarities and differences. I consider that these asynchronous dialogues are very useful for reviewing former or contemporary theoretical approaches under a different light. Researchers like Couldry have indicated the limits of the 'convergence culture' approach, in this context the confrontation with JMB's mediation theory can open new research paths to contemporary media and cultural studies.

As a conclusion, it could be said that the categories and analytical approaches developed by Latin American media research - which cannot be reduced to only JMB's contributions - could be very useful for understanding communication and cultural processes in an increasingly complex world. For example categories like JMB's mediation or García Canclini's borderland culture could be applied in any situation in which there is a conflict between cultures. The analysis of the always-critical cohabitation of cultures in the postmodern megalopolis, the rising of national democratic movements in Europe (from Catalonia to Scotland) with a strong cultural agenda, and the challenges of the network-society could be understood better if we include categories and approaches developed in an academic environment marked by 500 years of intercultural conflicts, exchanges, translations and misunderstandings. 


\section{References}

Adorno, T. \& Horkheimer, M. (2002). Dialectic of Enlightenment. Stanford, CA: Stanford University Press.

Althusser, L. (1971). Ideology and Ideological State Apparatuses. In L. Althusser Lenin and Philosophy, and Other Essays. London: New Left Books, pp. 127-188.

Arcila Calderón, C., Calderin, M. \& Castro, C. (eds.) (2014). An overview of digital media in Latin America. London: University of West London [VISTAS publications series No. 1].

Barthes, R. (1957). Mythologies. Paris: Seuil (English edition: Mythologies. London: Paladin, 1972).

Busse, K. \& Hellekson, K. (eds.) (2006). Fanfiction and Fan Communities in the Age of the Internet: New Essays. New York: McFarland.

Cardoso, F. H. \& Faletto, E. (1969). Dependencia y Desarrollo en America Latina. Mexico: Siglo XXI.

Castells, M. (2007). Communication, Power and Counter-power in the Network Society. International Journal of Communication, 1, 238-266. doi: 19328036/20070238. Retrieved from: http://ijoc.org/index.php/ijoc/article/viewFile/46/35

Cova, B., Kozinets, R.V. \& Shankar, A. (eds.) (2007). Consumer Tribes. Oxford: Elsevier / Butterworth Heinemann.

Couldry, N. (2011). More Sociology, More Culture, More Politics. Or, a modest proposal for 'convergence' studies. Cultural Studies, 25, 4/5, 487-501, doi: $10.1080 / 09502386.2011 .600528$

Delwiche, A. \& Henderson, J.J. (eds.) (2013). The Participatory Cultures Handbook. London: Routledge

Deuze, M. (2007). Media Work. Cambridge: Polity Press.

FELAFACS / UNESCO (2009). Informe Final del Proyecto: Mapa de los centros y programas de formación en Comunicación y Periodismo en América Latina y el Caribe. Lima (Perú): FELAFACS /UNESCO.

Fidler, R. (1997). Mediamorphosis. Understanding New Media. Thousand Oaks, CA: Pine Forge Press.

Ford, A.; Rivera, J. \& Romano, E. (1985). Medios de comunicación y cultura popular. Buenos Aires: Legasa.

García Canclini, N. (1993). Transforming Modernity. Popular Culture in Mexico. 
Austin, TX: University of Texas Press (Orig. edition: Culturas Populares en el Capitalismo, Mexico: Nueva Imagen, 1982).

García Canclini, N. (1995) Hybrid Cultures. Strategies for Entering and Leaving Modernity. Minneapolis, MN: University of Minnesota Press (Orig. edition:

Culturas Hibridas. Estrategias para entrar y salir de la Modernidad. Mexico: Grijalbo 1989).

González, J. A. (1996) La Cultura en México. México: Ed. Universidad de Colima. Gray, J., Sandvoss, C. \& Harrington, C.L. (eds.) (2007). Fandom: Identities and Communities in a Mediated World. New York: NYU Press.

Jenkins, H. (1992). What Made Pistachio Nuts? Early Sound Comedy and the Vaudeville Aesthetic. New York: Columbia University Press.

Jenkins, H. (2004). The cultural logic of media convergence. International Journal ofCultural Studies, 7(1), 33-43.

Jenkins, H. (2006a). Fans, Bloggers, and Gamers: Exploring Participatory Culture. New York, NY: New York University Press.

Jenkins, H. (2006b). Convergence Culture: Where Old and New Media Collide. New York, NY: New York University Press.

Jenkins, H., Ford, S. \& Green, J. (2013). Spreadable Media. Creating Value and Meaning in a Networked Culture. New York, NY: New York University Press.

Kindle Worlds (s/d). New stories inspired by books, shows, movies, comics, music, and games people love. Retrieved from:

http://www.amazon.com/gp/feature.html?docId=1001197421

Kuhn, T. (1962). The Structure of Scientific Revolutions. Chicago, IL: University of Chicago Press.

Martín-Barbero, J. (1978). Comunicación Masiva: Discurso y poder. Quito, Ecuador: CIESPAL.

Martín-Barbero, J. (1980). Retos a la Investigación de Comunicación en América Latina. Memoria de la Semana Internacional de la Comunicación. Bogotá: Universidad Javeriana. September 15, 2014. Retrieved from: http://www.mediaciones.net/1980/01/retos-a-la-investigacion-de-comunicacionen-america-latina/

Martín-Barbero, J. (1989). Panorama bibliográfico de la investigación latinoamericana en Comunicación. Telos 19, 140-146.

Martín-Barbero, J. (1993). Communication, Culture and Hegemony: From the Media to 
Mediations, London: Sage (Orig. edition: De los Medios a las Mediaciones. Comunicación, cultura y hegemonía. Mexico: Gustavo Gilli, 1987).

Martín-Barbero, J. (1999). Interview with Dr. Jesús Martín-Barbero by Adelaida Trujillo for The Communication Initiative Network. Retrieved from: http://www.comminit.com/node/149538

Martín-Barbero, J. (2005). Cultura y nuevas mediaciones tecnológicas. In Convenio Andrés Bello (ed.) América Latina: otras visiones de la cultura. Bogotá, Colombia. Retrieved from: http://es.scribd.com/doc/6313584/Cultura-y-nuevasmediaciones-tecnologicas

Martín-Barbero, J. (2006). A Latin American perspective on communication/cultural mediation. Global Media and Communication 2, 279-297. doi: $10.1177 / 1742766506069579$

Martín-Barbero, J. (2012). Prólogo-entrevista. In J. Bonilla, M. Marión Castaño, O. Rincón \& J. Zuluaga (eds.). De las audiencias contemplativas a los productores conectados: mapa de los estudios y de las tendencias de ciudadanos mediáticos en Colombia. Cali, Colombia: Sello Editorial Javeriano.

Mattelart, A. (1970). El marco del análisis ideológico. Cuadernos de la Realidad Nacional, 3. Santiago de Chile: Ed. Universidad Católica.

Orozco Gómez, Guillermo (1996) Televisión y Audiencias. Un enfoque cualitativo. Mexico: Ediciones de la Torre.

Ortiz, R. (1985). Cultura Brasileira e Identidade Nacional. São Paulo: Brasiliense.

Rogers, E. M. (1962). Diffusion of Innovations. New York, NY: Free Press.

Schlesinger, P. (1993). Introduction. In J. Martín-Barbero, Communication, Culture and Hegemony. From the Media to Mediations (pp. viii-xv). London: Sage.

Schlesinger, Philip and Morris, Nancy (1997). Cultural Boundaries: Identity and Communication in Latin America. Media Development, 44(1), 5-17. Retrieved from: http://www.irfanerdogan.com/cultureideology/culture.html

Schramm, W. (1964). Mass Media and National Development. Stanford, CA: Stanford University Press.

Scolari, C. A. (2008). Hipermediaciones. Elementos para una teoría de la comunicación digital interactiva. Barcelona: Gedisa.

Scolari, C. A. (2009). Mapping conversations about new media: the theoretical field of digital communication. New Media \& Society, 11(6), 943-964. doi: 
Scolari, C. A. (2012). Media Ecology: Exploring the Metaphor to Expand the Theory. Communication Theory, 22(2), 204-225. doi: 10.1111/j.14682885.2012.01404.x

Scolari, C. A. (2013). Lostology. Transmedia storytelling and expansion/compression strategies. Semiotica 195, 45-68.

Scolari, C. A. (2014). Don Quixote of La Mancha: Transmedia Storytelling in the Grey Zone. International Journal of Communication, 8, 1-20. doi: 1932$8036 / 20140005$

Scolari, C. A., Bertetti, P. \& Freeman, M. (2014). Transmedia Archaeology Storytelling in the borderlines of science fiction, comics and pulp magazines. New York, NY: Palgrave. 